Agnieszka Zabłocka-Kos

Instytut Historii Sztuki, Uniwersytet Wrocławski

ORCID: 0000-0002-5602-6387

\title{
„Hin sinkt der Wall, der alte Schutz, es fallen seine Stützen”. Ryska twierdza w XVI-XIX w. i jej defortyfikacja w 1857 r. ${ }^{1}$
}

DOI: https://doi.org/10.26881/porta.2020.19.14

Na początku XIX w. na wybrzeżu Bałtyku, na wschód od Odry, znajdowały się cztery dobrze ufortyfikowane średniowieczne miasta handlowe: Szczecin, Gdańsk, Królewiec i Ryga. Już w 1814 r. w Królewcu postanowiono rozebrać średniowieczne umocnienia i na ich miejscu założyć promenadę. Działania te nie przełożyły się jednak na stworzenie reprezentacyjnego założenia, a przekształcenie miasta około połowy XIX w. w jedną z najważniejszych twierdz pruskich wstrzymało jego przestrzenny rozwój aż do końca pierwszej wojny światowej². Podobny los spotkał Gdańsk, zdefortyfikowany dopiero na początku XX w. ${ }^{3}$ Szczecin i Ryga pozbyły się swych umocnień w drugiej połowie XIX stulecia: Szczecin od 1873 r. ${ }^{4}$, Ryga zaś najwcześniej i najbardziej uroczyście - w 1857 r.

1 Artykuł powstał w ramach projektu „Eroberung der City. Politische Architektur in Mitteleuropa 1815-1918" realizowanego w ramach rocznego pobytu w latach 2011-2012 we Freiburg Institute for Advanced Studies przy Albert-Ludwig-Universität in Freiburg/Br. oraz miesięcznego stypendium naukowego w Herder-Institut für historische Ostmitteleuropaforschung - Institut der Leibniz-Gemeinschaft. Za pomoc przy opracowywaniu materiałów dotyczących Rygi pragnę podziękować dr Agnes Bergholde-Wolf z Marburga oraz dr Dainie Lāce z Rygi. Pierwsza część tytułu jest tytułem hymnu odśpiewanego podczas uroczystej inauguracji prac defortyfikacyjnych, cyt. za: Friedrich Brunstermann, Die Geschichte der Kleinen oder St. Johannis-Gilde in Wort und Bild (zum Jubiläumsjahr 1901), Riga 1902, s. 487.

2 Fritz Beuster, Entfestigung der Innenstadt und Umgestaltung der Verkehrsanlagen in Königsberg i. Pr., Königsberg 1913.

3 Małgorzata Omilanowska, Defortyfikacja Gdańska na tle przekształceń miast niemieckich w XIX wieku, „Biuletyn Historii Sztuki” 2010, nr 3, s. 293-334; eadem, Die Entfestigung Danzigs im Kontext der Umgestaltung der deutsche Städte im Laufe des 19. Jahrhunderts [w:] Das maritime Stadt. Hafenstädte an der Ostsee vom Mittelalter bis in die Gegenwart: Beiträge der 21. Tagung des Arbeitskreises deutscher und polnischer Kunsthistoriker und Denkmalpfleger in Gdańsk 18-21 September 2013, Hg. Tomasz Torbus, Katarzyna Anna Wojtczak, Warszawa 2017 (Wspólne Dziedzictwo, t. 10 / Das Gemeinsame Kulturerbe, Bd. 10), s. 315-360.

4 Bogdana Kozińska, Rozwój przestrzenny Szczecina od początku XIX wieku do II wojny światowej, Szczecin 2002, s. 146-197. 
Agnieszka Zabłocka- Kos

Niniejszy artykuł poświęcony jest fortyfikowaniu Rygi w XVII i XVIII w. i związanym $\mathrm{z}$ tym planom przedmieść oraz rozbiórce murów i nowej koncepcji rozwoju przestrzennego miasta. Na podstawie licznych projektów dla terenów pozostałych po nowożytnych umocnieniach władze miasta i prowincji, architekci i fundatorzy wykreowali jedno z najciekawszych i najpiękniejszych europejskich dziewiętnastowiecznych założeń promenadowych.

Ryga, średniowieczne miasto hanzeatyckie, założone w 1201 r., była przez wieki jednym z najważniejszych portów bałtyckich, a od początku XVIII w. - morskimi wrotami otwierającymi drogę w głąb Imperium Rosyjskiego. Jej handlowo-militarne znaczenie wymusiło budowę efektywnego systemu obronnego. Pierwszy pierścień umocnień powstał już w XIII-XIV w. Tworzył go wysoki mur opasujący miasto także od strony Dźwiny i portu ${ }^{5}$. W krótkim okresie przynależności Rygi do Rzeczypospolitej (1561-1621), w czasach panowania Stefana Batorego, przebudowano część fortyfikacji w systemie włoskim, a niektórym bramom nadano reprezentacyjne formy ${ }^{6}$. W pierwszej połowie XVII w., już w czasach szwedzkich (1621-1721), miasto ujęto w system bastionów, wałów ziemnych i fos typu holenderskiego (il. 1). Następnie fortyfikacje te poszerzono o kolejną linię bastionów, wałów i palisadę, którymi otoczono przedmieścia. W pierwszej połowie XVII w. powstał bardzo interesujący pierwszy plan ich zabudowy autorstwa niemieckiego inżyniera Johana van Rodenburga (zm. 1660), oparty na regularnej siatce ulic i kwartałów $(1652$, il. 2) 7 . Został on częściowo zrealizowany i stał się podstawą dla późniejszych przekształceń przedmieść.

W wyniku wojen północnych szwedzką część Inflant wraz z Rygą przyłączono w 1721 r. do Imperium Rosyjskiego. Duże zniszczenia wojenne spowodowały, że w drugiej połowie XVIII w. podjęto kolejne prace regulacyjne. W $1769 \mathrm{r}$. Rudolf Friedrich Härbel, pochodzący ze Szwajcarii inżynier w randze generał-majora, chcąc stworzyć nową koncepcję obrony miasta, opracował kolejny plan przedmieść ${ }^{8}$ (il. 3). Przewidywał on pozostawienie glacis przed umocnieniami miasta lokacyjnego i połączenie go z regularną esplanadą o szerokości około $400 \mathrm{~m}$. Miasto średniowieczne zyskałoby tym samym bardzo szeroki pas wolny od zabudowy (łącznie około $900 \mathrm{~m}$ ). Sądzono, że stanowiłby on wystarczające przedpole do skutecznej obrony. Za esplanadą mogłyby się swobodnie rozwinąć przedmieścia, czemu służyłaby częściowa likwidacja zewnętrznej linii umocnień.

5 Wilhelm Neumann, Das mittelalterliche Riga, Berlin 1892, s. 6 n.; Carla Redlich, Das älteste Riga und die Stuben zu Münster und Soest, „Zeitschrift für Ostforschung” 1988, nr 4, s. 555-580.

6 Riga und seine Bauten, Ryga 1903, s. 42; Paul Campe, Die Stadtore Riga im 17., 18., 19. Jh. und deren Meister [w:] Latvijas Universitates Raksti Acta Universitatis Latviensis Architektura Fakultates Serija II. 3, Riga 1939, s. 241-264; Kevin C. O'Connor, The House of Hemp and Butter: A History of Old Riga, New York 2019, s. 199 n. Na temat historii rozwoju przestrzennego Rygi w XVII-XX w. zob. Irēna Bākule, Arnis Siksna, Rìga ārpus nocietinājumiem: pilsētas plānota izbüve un pärbuve. Riga beyond the walls. The city's planned growth and transformation from the 17 th century to the First World War, Riga 2009, s. 26-31.

O'Connor, The House..., s. 202-206; Bākule, Siksna, Rìga ärpus..., s. 35-58.

Ibidem, s. 78-82. 


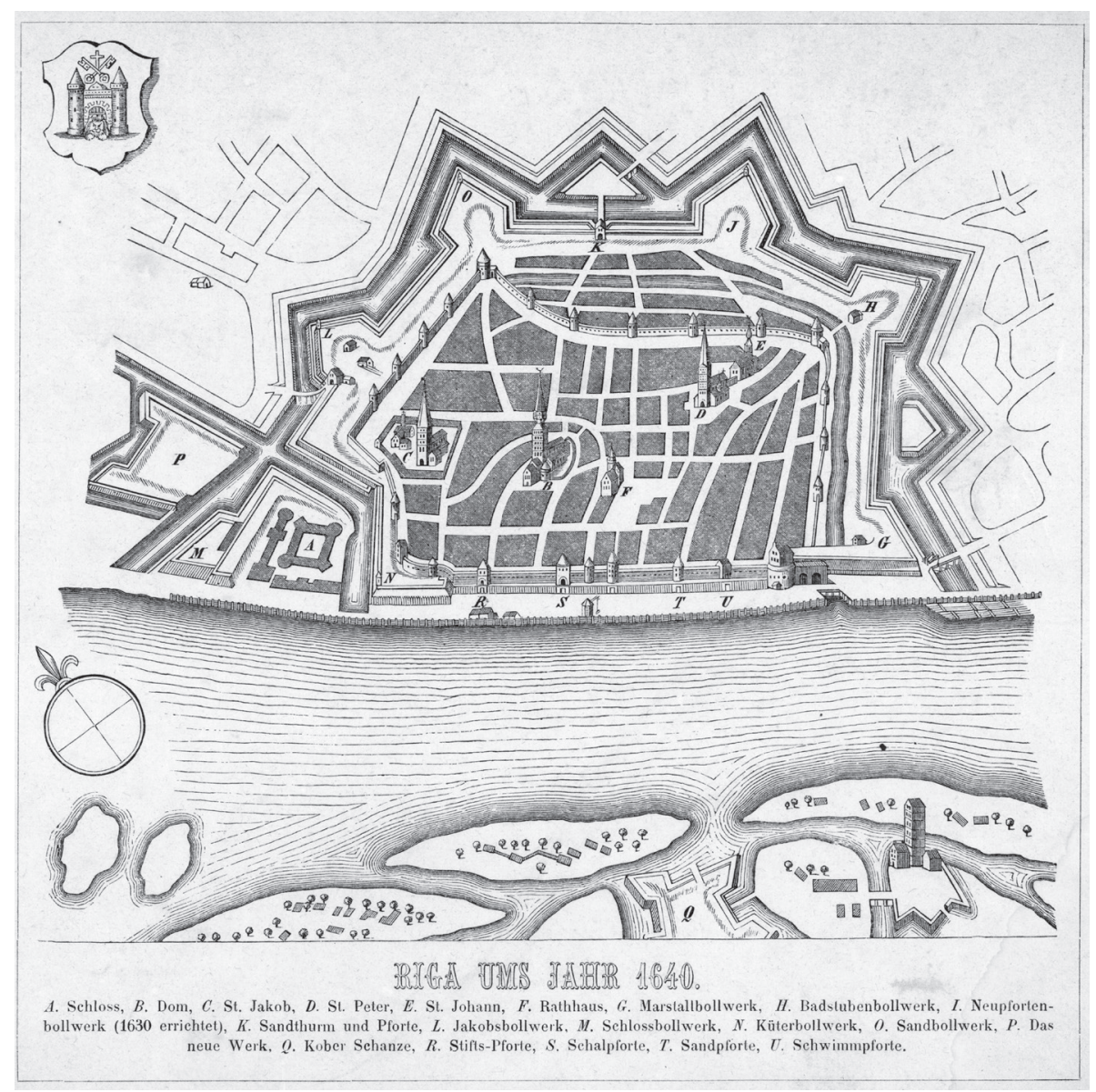

Hin sinkt der Wall...

Il. 1. Ryga, widok od strony Dźwiny, około 1640, Herder Institut Marburg, Kartensammlung sygn. K 46 VIII R 27 -R, repr. za: Matthäus Merian, wyd. 1. w: J. Angelius von Wedenhagen, De rebuspublicic hanseaticis, Frankfurt 1641

Härbel zaprojektował regularne bloki zabudowy, powtarzając częściowo układ z planu Rodenburga ${ }^{9}$. Zarówno koncepcja Rodenburga, jak i Härbela zakładały dynamiczny rozwój przedmieść, związany niewątpliwie z silną pozycją handlową Rygi w tej części Bałtyku.

Oba projekty były także świadectwem dokonującej się przemiany w planowaniu urbanistycznym: o ile według Rodeburga miasto było jeszcze w całości zamknięte i ufortyfikowane, o tyle według Härbela było już półotwarte. W tym drugim przypadku, gdyby wybuchła wojna, przedmieścia byłyby wprawdzie narażone na zniszczenie, ale miasto lokacyjne, ze względu na szeroki niezabudowany teren, uzyskałoby nowe możliwości obronne. Ta koncepcja 


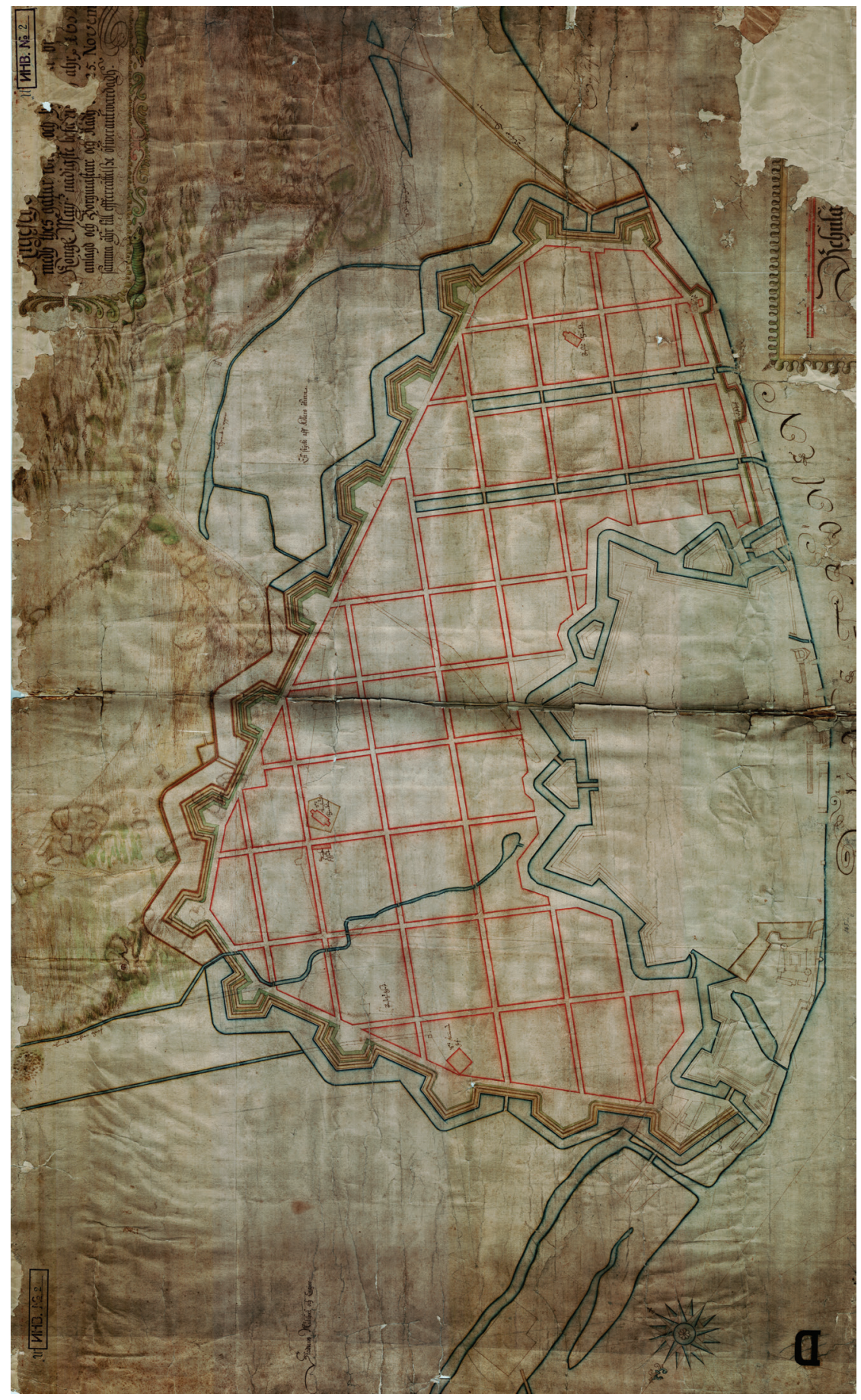

Il. 2. Johann van Rodenburg, projekt nowych przedmieść i ich ufortyfikowania, 1652, Rīgas vēstures un kuğniecības muzejs (Muzeum Historii Rygi i Nawigacji), Ryga, sygn. VRVM 31122 


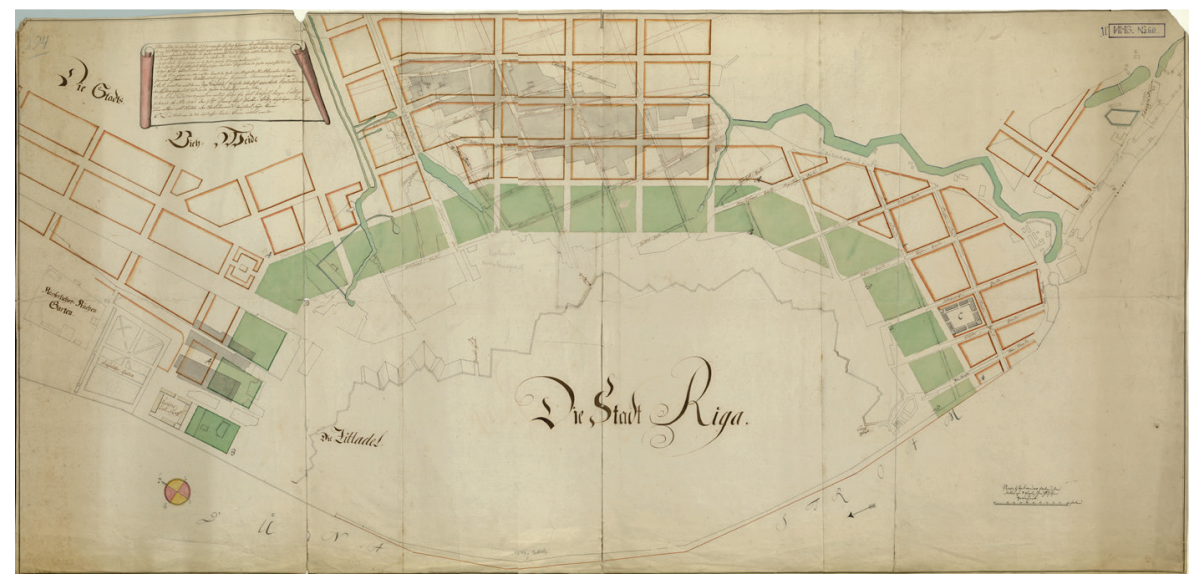

Hin sinkt der Wall...

Il. 3. Rudolf Friedrich Härbel, projekt esplanady i nowych przedmieść, 1769, Rīgas vēstures un kuğniecības muzejs (Muzeum Historii Rygi i Nawigacji), Ryga, sygn. VRVM 1619

była $\mathrm{w}$ pełni zgodna $\mathrm{z}$ ówczesnymi technikami wojskowymi. Plan Härbela uznaje się wprawdzie bardziej za szkic projektowy niż projekt realizacyjny, była to jednak niezwykle interesująca i dalekosiężna koncepcja rozwoju miasta, o skutkach trudnych wówczas do przewidzenia. Widać to dobrze na planie z 1797 r., na którym regularne bloki przedmieścia zachodniego (Przedmieście Petersburskie) i mniej regularne bloki przedmieścia północnego (Przedmieście Moskiewskie) są już (szczególnie przy głównych drogach i wzdłuż esplanady) zabudowane (il. 4). W drugiej połowie XVIII w. wyznaczono zatem przestrzenny układ przedmieść, który stał się ramą dla ich przyszłego rozwoju. Wytyczenie szerokiego niezabudowanego przedpola przed miastem lokacyjnym i esplanady (częściowo już wtedy rekreacyjnie użytkowanej) stanowiło podstawę do ich reprezentacyjnego zagospodarowania w drugiej połowie XIX w.

W 1812 r. przyszła jednak katastrofa. W obawie przed oblężeniem przez sprzymierzoną wówczas z Napoleonem armię pruską general-gubernator, Magnus Gustav von Essen (1758-1813), wydał w lipcu 1812 r. rozkaz podpalenia obu przedmieść ${ }^{10}$. Były one zabudowane głównie drewnianymi domami, które w całości strawił pożar, około czterech tysięcy mieszkańców zostało bez dachu nad głową ${ }^{11}$. Ten zapobiegawczy (często stosowany) manewr obronny okazał się

10 W czerwcu 1812 r. ogłoszono w Rydze stan wojenny. O przygotowaniach do obrony, podpaleniu przedmieść i oblężeniu zob. Aleksandr I. Michajłowski-Danilewski, Geschichte des vaterländischen Krieges im Jahre 1812, auf Allerhöchsten Befehl Sr. Majestät des Kaisers von Russland verfaßt von Michailowsky Danilewsky, Generalleutenant, Senateur und Mitglied des Kriegsraths. Theil 1, Riga-Leipzig 1840, s. 348-359.

11 Ibidem, s. 355. Spalono 4 kościoły, 25 budynków miejskich, 416 budynków na Przedmieściu Petersburskim, 286 na Przedmieściu Moskiewskim, 117 na Przedmieściu Mitawskim. Ogólne straty wyniosły 16821543 rubli, zob. ibidem, s. 356. 


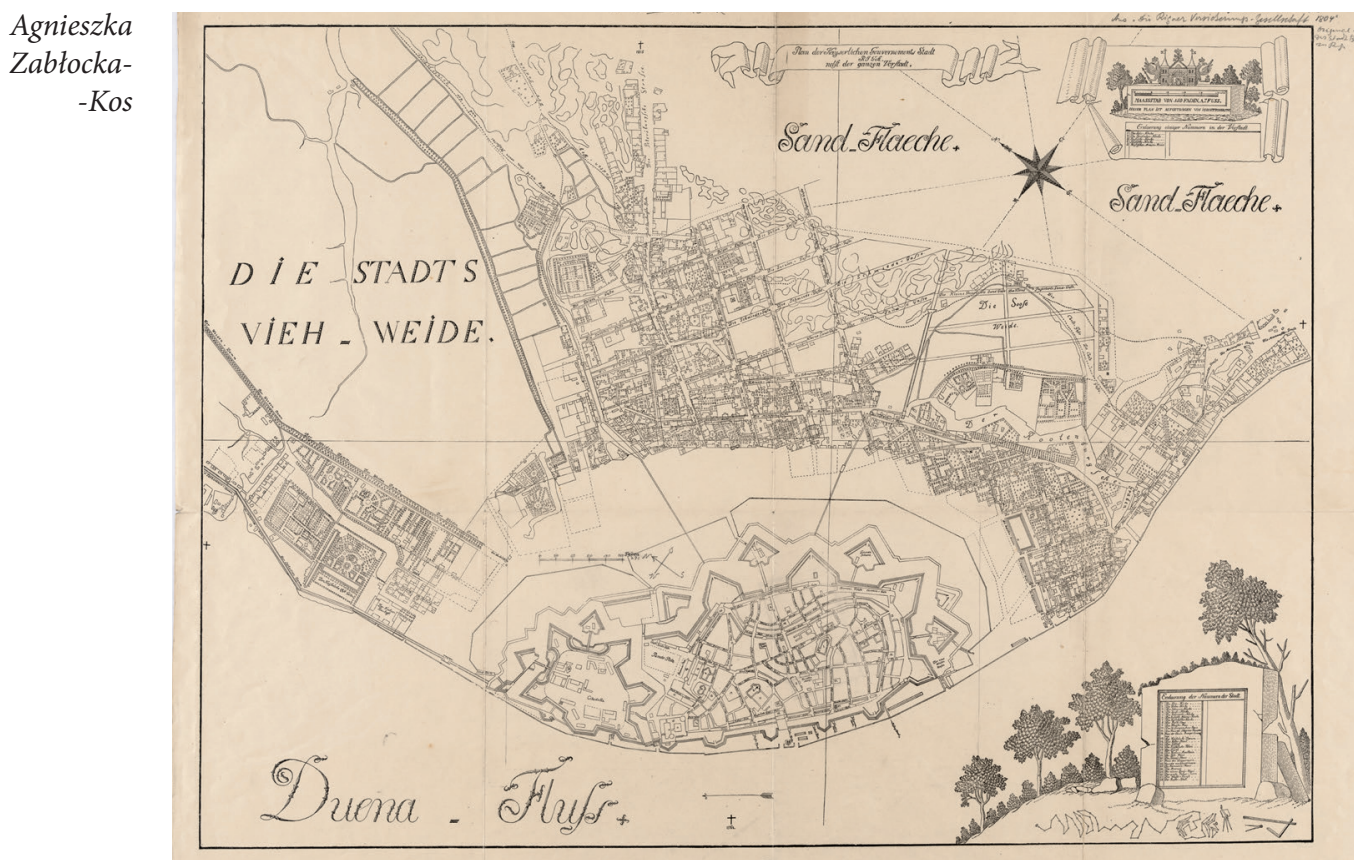

Il. 4. Plan der Kayserlichen Gouvernements Stadt Riga, nebst der ganzen Vorstadt, bearb.

J. Groettcher, Riga 1804 (1797), Herder Institut Marburg, Kartensammlung sygn. K 46 VIII R 15-R

bezużyteczny, bowiem Prusacy nie podjęli ataku na Rygę, stał się jednak ostatecznym impulsem do opracowania nowego projektu przedmieść.

Już w 1813 r. opublikowano przepisy budowlane obejmujące nowy plan zabudowy. Opracował je oddelegowany do Rygi markiz Filippo Paulucci (1779-1849), z pochodzenia Włoch, pozostający od 1807 r. w służbie wojska rosyjskiego $^{12}$. W $1812 \mathrm{r}$. objął on po Essenie stanowisko ryskiego gubernatora wojennego i dowódcy korpusu oraz generał-gubernatora guberni inflackiej (liwońskiej). Ryga miała nadal pozostać twierdzą, zlikwidowano jednak całkowicie zewnętrzne, osiemnastowieczne obwarowania, mury obronne miało mieć tylko miasto lokacyjne.

Tym samym podjęto decyzję, która stała w pewnej sprzeczności z panującą wówczas tendencją do defortyfikacji miast. W związku z wojnami prowadzonymi przez Napoleona I nastąpiła bowiem w Europie Środkowej gwałtowna fala likwidacji umocnień ${ }^{13}$. Decyzja o pozostawieniu szerokiego niezabudowanego pasa przed

12 Virgilio Ilari, Maurizio Lo Re, Tatiana Polomochnykh, Piero Crociani, Маркиз Паулуччи. Filippo Paulucci delle Roncole (1799-1849), Roma 2013.

13 Temat defortyfikacji miast niemieckich szeroko opisał Yair Mintzker, The Defortification of the German City, 1689-1866, Cambridge 2012. Warto też zwrócić uwagę na rolę kreacji reprezentacyjnej ulicy na obrzeżu starego miasta w Atenach od lat trzydziestych XIX w., którą można uznać za „protoring” wiedeński. Założenie w Atenach, stworzone przez architektów monachijskich, 
miastem lokacyjnym i zezwolenie na limitowaną rozbudowę przedmieść Rygi było rozwiązaniem kompromisowym. Zakładano wprawdzie, że w wyniku ewentualnych działań wojennych mogą zostać zniszczone tereny przed murami, ale liczono na skuteczną obronę gęsto zaludnionego obszaru miasta średniowiecznego.

Paulucci podszedł do odbudowy przedmieść metodycznie, opracowując w $1813 \mathrm{r}$. nowy plan Rygi, skorelowany ze szczegółowymi przepisami ${ }^{14}$ (il. 5). Obszar poza murami został podzielony na pięć stref. Pierwsza, zewnętrzna, licząc od korony glacis, miała $277 \mathrm{~m}$ (130 sążni $)^{15} \mathrm{i}$ zawierała nieprzeznaczony pod zabudowę teren $170 \mathrm{~m}$ (80 sążni), nazwany esplanadą, ujmujący stare miasto od strony południowej i północnej (C). Strefa ta była otoczona dwurzędowymi alejami i częściowo zaplanowana jako park angielski ${ }^{16}$. Od strony zewnętrznej przylegały do niej ogrody warzywne (Küchengärten), o szerokości 106 m (D). Pośrodku tego założenia, przy głównej czterorzędowej alei wjazdowej do miasta, wytyczono obszerny plac ćwiczeń (E). Niezabudowany teren ujmowały szerokie drogi oraz ścieżki spacerowe.

Pozostałe trzy strefy obejmujące przedmieścia miały ściśle reglamentowaną zabudowę. Domy miały być niepodpiwniczone, jednopiętrowe, drewniane, a ich fasady - oparte na zaleconych przez władze wzorcowych rozwiązaniach i zatwierdzone w odpowiednim urzędzie budowlanym. Dopiero w zewnętrznej, ostatniej strefie, domy mogły być wznoszone w technice muru pruskiego i mieć murowane fundamenty. Przestrzegano też, że ten, kto zdecyduje się na budowę domu w obrębie twierdzy, nie może liczyć na wypłatę odszkodowania, jeśli jego własność zostanie zniszczona w wyniku oblężenia miasta.

W przepisach szczególną wagę przykładano do kreowania estetyki nowych przedmieść. Nie tylko nakazano wznoszenie elewacji według zaproponowanych wzorów, lecz także zalecono dostosowanie zabudowy do wytyczonych linii regulacyjnych. Miało to służyć utrzymaniu jednorodnego wyglądu ulic ${ }^{17}$. Równocześnie zabroniono budowy na głównych ulicach obiektów uciążliwych, takich jak np. jatki czy rzeźnie, które można było wznieść tylko w miejscu wskazanym przez urząd budowlany.

stało się niewątpliwie wzorcem dla monumentalnych dziewiętnastowiecznych założeń powstających na terenach pofortyfikacyjnych w miastach Europy Środkowej i Wschodniej, zob. Eleni Bastéa, The Creation of Modern Athens. Planning the Myth, Cambridge 2000. W kontekście tego artykułu wskazano na nowe możliwe wzorce dla Rygi. Defortyfikacja Rygi w kontekście europejskim mogłaby być przedmiotem osobnego studium.

14 Opis przepisów odbudowy zob. Reglement über die Wiederaufbauung der Rigaschen Vorstädte und das Verhältniß der Vorstädte zu den Befestigungen von Riga, Riga 1813. Zob. Bākule, Siksna, Rìga ärpus..., s. 118-129.

15 Według przepisów wprowadzonych w Rosji w 1835 r. 1 sążęń równał się 2,134 metra.

16 Był to pierwszy park publiczny w Rydze, nazwany później parkiem Wöhrmanna od nazwiska głównego donatora - konsula pruskiego.

${ }_{17}$ Wzorcowe domy dla przedmieść zob. Русское градостроительное искусство. Градостроительство России середины XIX - начала XX века. Книга вторая. Под общей редакцией Е. И. Кириченко, Москва 2003, s. 37-54 (o nowych przepisach z 1815 r. zob. s. 44). 


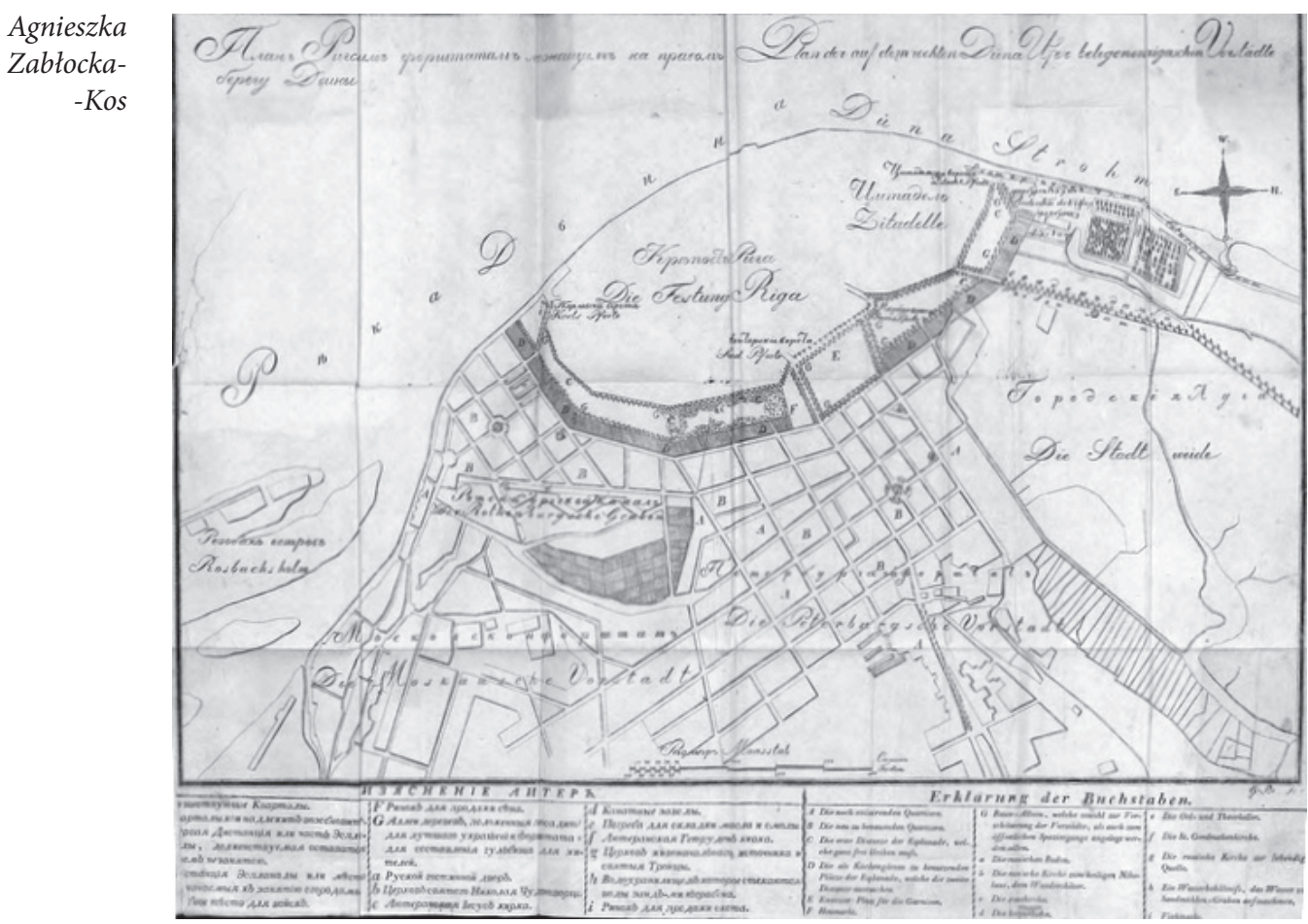

Il. 5. Plan przedmieść Rygi położonych na prawym brzegu Dźwiny według koncepcji Filippa Paulucciego, 1813, repr. za: Reglement über die Wiederaufbauung der Rigaschen Vorstädte und das Verhältniß der Vorstädte zu den Befestigungen von Riga, Riga 1813, s. 26-26

Plan regulacyjny przedmieść był oparty na siatce prostokątnych bloków. Koncepcja ta nawiązywała wyraźnie do planu Häberlego, jednak w nowym projekcie bloki były zdecydowanie mniejsze i bardziej regularne, a sieć ulic - gęstsza. Na każdym z przedmieść wytyczono wielokątne place dla dwóch kościołów ewangelickich: na Przedmieściu Moskiewskim dla kościoła im. Jezusa (Jesus-Kirche), na Przedmieściu Petersburskim dla kościoła św. Gertrudy (St. Gertrudkirche). Place stanowiły punkty krystalizacyjne dla kształtowania się nowej zabudowy.

Wytyczne i plan Paulucciego opierały się na przepisach pruskich, opracowanych w czasach Fryderyka II i stosowanych do odbudowy miast po zniszczeniach wojennych i pożarach. Nie przewidziano jednak wsparcia finansowego państwa, co było regułą $\mathrm{w}$ przepisach pruskich, a jedynie zwolnienia $\mathrm{z}$ podatków i konieczności kwaterowania żołnierzy ${ }^{18}$. Plan Paulucciego należy zaliczyć do najbardziej interesujących koncepcji tzw. Retablissement na terenie Imperium Rosyjskiego. Stał się on podstawą dla rozwoju przestrzennego Rygi (niemal

18 Retablissement: preußische Stadtbaukunst in Polen und Deutschland. Urbanistyka pruska w Polsce i w Niemczech, Hg. Christof Baier, André Bischoff, Joanna Drejer i in., Berlin 2016. 
po dzisiejsze czasy). Jego największą zaletą było wytyczenie esplanady o szerokości około 300-400 m, co pozwoliło wyznaczyć (podobnie jak w Wiedniu) der Wall... przestrzeń dla reprezentacyjnych budowli użyteczności publicznej i pałacowych kamienic, wzniesionych już po defortyfikacji.

Zanim to jednak nastąpiło, Ryga trwała w okowach murów i bastionów, pozbawiona możliwości pełnego rozwoju przestrzennego. Zachowany w Instytucie Herdera w Marburgu niezwykle interesujący plan Adress-Karte und Plan von Riga z 1843 r. przedstawia podział obszaru staromiejskiego na cztery dzielnice i na poszczególne parcele. Jest on nie tylko planem miasta lokacyjnego, lecz także księgą adresową właścicieli poszczególnych posesji (łącznie z podaniem ich zawodów) ${ }^{19}$. Można z niego też odczytać lokalizację najważniejszych urzędów i instytucji. Nieregularna sieć ulic i gęsta zabudowa odzwierciedlają bardzo trudną sytuację starego miasta tuż przed likwidacją umocnień. Nie było tu już żadnych wolnych działek, a nowe budynki mogły powstać tylko w wyniku wykupienia i komasacji gruntów, co zresztą wkrótce nastąpiło w związku $\mathrm{z}$ budową giełdy.

Plan miasta jest ujęty neorokokową bordiurą - w jej górnej partii ukazano panoramę Rygi od strony Dźwiny, zwieńczoną orłem carskim, w lewym górnym rogu widnieje prawosławna katedra św. Piotra i Pawła ${ }^{20} \mathrm{w}$ cytadeli przy siedzibie gubernatora, a w prawym górnym - cerkiew św. Mikołaja na Przedmieściu Petersburskim. Górna część bordiury reprezentowała zatem miasto, jego władze i najważniejsze kościoły religii państwowej. Odpowiednikiem rysunku panoramy miasta był umieszczony w środkowej partii dolnej bordiury widok pałacu gubernatora $\mathrm{w}$ dawnej cytadeli wraz herbem Rygi, $\mathrm{w}$ dolnych rogach umieszczono zaś widoki świątyń ewangelicko-luterańskich: kościoła im. Jezusa (w lewym rogu) i katedry św. Jakuba (w prawym rogu). W ten sposób plan reprezentował dwie najważniejsze grupy narodowe zamieszkujące Rygę: będących w mniejszości prawosławnych Rosjan, głównie wojskowych i przedstawicieli władzy, i protestanckich Niemców, stanowiących większość mieszkańców. Lewą boczną bordiurę zdobi figura kobieca z kaduceuszem i trójzębem - alegoria handlu lądowego i morskiego. Nad nią widnieje rysunek kotwicy, beczki i pakunków, a pod nią - przedstawienie kupca $\mathrm{z}$ wozem pełnym towarów. W bocznej bordiurze po prawej stronie umieszczono postać kobiety z rogiem obfitości, kotwicą, pierścieniami i kołem jako symbolem rzemiosła. To alegoria pomyślności płynącej z handlu morskiego i wytwórczości. Nad nią znajduje się rysunek beczek i masztu statku, pod nią zaś - widok żaglowca na tle ufortyfikowanego miasta.

\footnotetext{
19 W ryskim Muzeum Historii Rygi i Nawigacji (Rīgas vēstures un kuǵniecỉbas muzejs) zachował się także podobny plan z 1826 r., ale nie tak dekoracyjnie opracowany jak plan z Marburga (sygn. VRVM 31141). Niezależnie od niego publikowano też księgi adresowe, np. Systematisch geordnetes Adreß-buch der Stadt Riga auf das Jahr 1846. Herausgegeben von Eduard v. Gruhl, Riga 1846.

20 Była to cerkiew garnizonowa, wzniesiona w 1785 r., od 1836 r. - siedziba wikariusza eparchii pskowskiej, od 1841 r. - siedziba biskupa.
} 
Agnieszka

Zabłocka-

- Kos

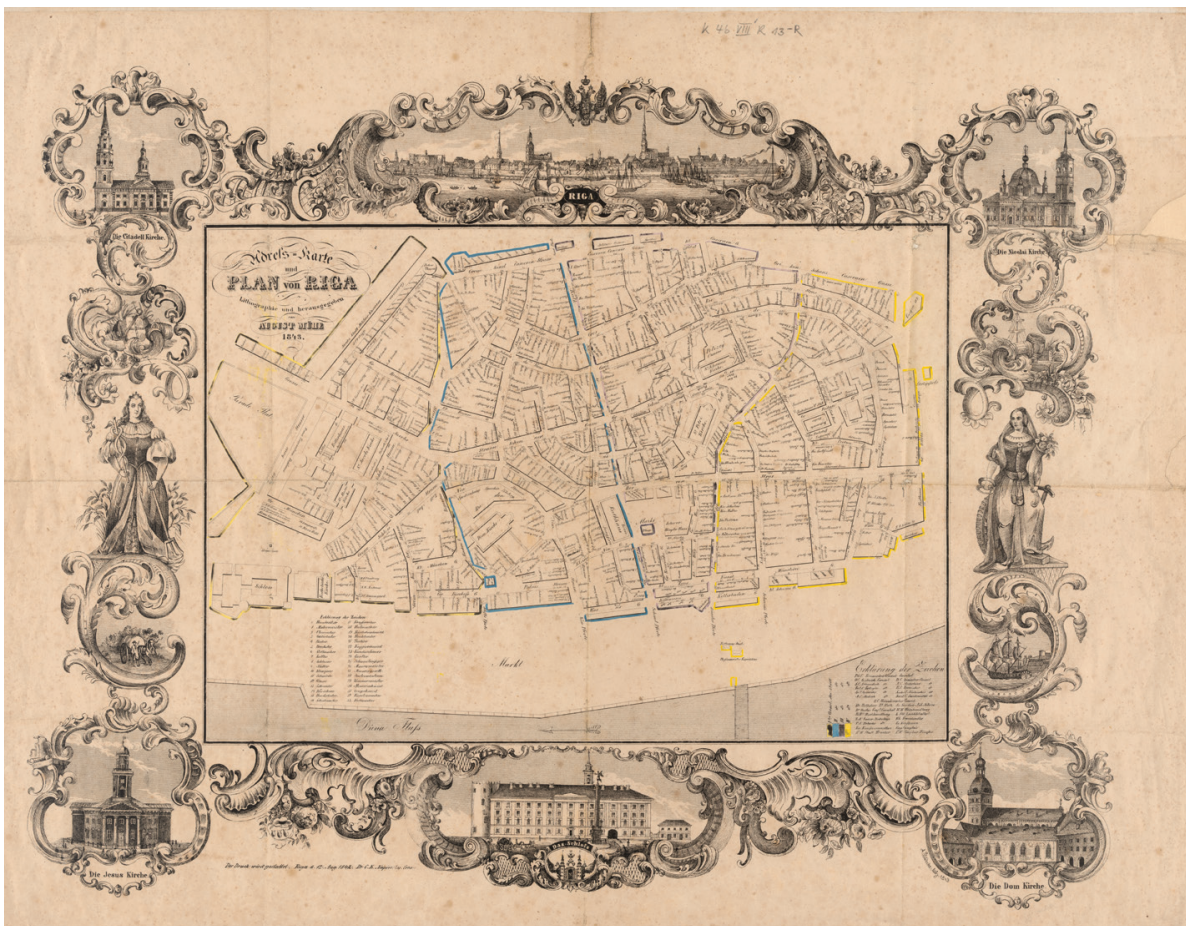

Il. 6. Adress-Karte und Plan von Riga, bearb. August Mühe, Riga 1843, Herder Institut Marburg, Kartensammlung sygn. K 46 VIII R 13

Plan jednoznacznie wskazuje, iż carskie miasto Ryga, z mieszkańcami wyznania prawosławnego i protestanckiego, szczyci się pomyślnością w handlu morskim (statki, trójząb) i lądowym oraz dobrobytem płynącym z rozwoju wszelkiej wytwórczości, głównie rzemiosła. Ta niewielka, wręcz podręczna mapa miasta, dająca się łatwo złożyć (wymiary po złożeniu - około $15 \times 20 \mathrm{~cm}$ ), ze wspaniałymi bordiurami w bardzo modnej wówczas stylistyce neorokoka ${ }^{21}$, była przeznaczona prawdopodobnie dla zagranicznych kupców (o czym świadczyłyby zaznaczone na niej siedziby konsulatów ${ }^{22}$ ), szukających kontaktu z miejscowymi handlarzami i rzemieślnikami (przy nazwisku każdego właściciela posesji zaznaczono symbol jego profesji, opisany w legendzie). Plan stanowił swoistą autopromocję Rygi - jako miasta kwitnącego handlu i wszelkiej produkcji. Nie zaznaczono jednak na nim fortyfikacji - elementu, który najbardziej blokował rozwój stolicy guberni inflanckiej.

${ }_{21}$ Zdzisława Tołłoczko, Neorokoko: z genealogii historyzmu w architekturze i sztuce XIX wieku, „Teka Komisji Urbanistyki i Architektury. Oddział PAN w Krakowie” 2001, t. 33, s. 109-131.

22 Według księgi adresowej z 1846 r. w Rydze mieściły się konsulaty Prus, Saksonii, Szwecji i Norwegii, Anglii, Holandii, Sardynii, Hiszpanii, Danii, Hanoweru, Wirtembergii, Francji, Belgii, Portugalii, Meklemburgii, Oldenburga, Austrii i Ameryki Północnej, zob. Systematisch geordnetes..., s. 33-34. 
Nie można się zatem dziwić, że władze komunalne i członkowie wpływowych gildii zaczęli czynić intensywne starania, by zlikwidować umocnienia bastionowe, a także uwolnić nabrzeże oddzielone od miasta murem, bramami i wieżami i umożliwić swobodny rozwój portu. W 1840 r. Ryga liczyła już 60000 mieszkańców i choć w ciągu kolejnych czterdziestu lat ich liczba się podwoiła ${ }^{23}$, to miasto wciąż pozostawało twierdzą. W 1854 r., podczas wojny krymskiej, podjęto (ostatnie już w dziejach miasta) przygotowania do obrony, wzmacniając wały ${ }^{24}$. Jednak doświadczenia militarne zdobyte podczas bitew tej kampanii dowiodły nieprzydatności nowożytnych umocnień, co tylko ułatwiło podjęcie decyzji o ich likwidacji. Angielska blokada morska portu w Rydze spowodowała wielkie trudności w handlu: w czasach pokoju cumowało to ponad dwa tysiące statków, a w 1855 r. tylko jedenaście!25 To uświadomiło kupcom ryskim, że istnieje jeszcze jedna istotna przeszkoda hamująca rozwój miasta - brak połączenia kolejowego z miastami Imperium. Wnioski płynące z blokady Rygi podczas wojny krymskiej - konieczność likwidacji twierdzy i otwarcie linii kolejowej, połączone z formułowanym już wcześniej postulatem budowy nowoczesnego portu - legły u podstaw fundamentalnych decyzji dotyczących przyszłości miasta. Popierał je Aleksandr Arkadjewicz, książę włoski, hrabia Suworow-Rymnikski (1804-1882), w latach 1848-1861 wojskowy gubernator Rygi i generał-gubernator trzech prowincji nadbałtyckich ${ }^{26}$. Absolwent uniwersytetu w Getyndze, świetnie obeznany z Europą, sprzyjał niemieckiej ludności prowincji bałtyckich i rozwojowi Rygi jako nowoczesnego miasta handlowego, co w odniesieniu do sympatii proniemieckich było w niektórych kręgach elit petersburskich przyjmowane dość nieprzechylnie.

Niewątpliwie to dzięki Suworowowi rozpoczęto pertraktacje dotyczące likwidacji twierdzy. W lutym $1856 \mathrm{r}$. wystosował on memoriał do cara Aleksandra $\mathrm{II}^{27}$. Podkreślał, że Ryga ma już 75000 mieszkańców, z czego aż 15000 mieszka w obrębie murów. Argumentował, że stłoczenie ludności w twierdzy było niebezpieczne z powodu występujących epidemii. W lecie przybywali do Rygi drogą wodną handlarze, których miasto nie mogło pomieścić. Brakowało miejsca

23 https://de.wikipedia.org/wiki/Riga [dostęp: 10.02.2020].

24 Constantin Mettig, Geschichte der Stadt Riga, Riga 1897, s. 453-454.

25 Bernhard Hollander, Riga im 19. Jahrhundert. Ein Rückblick von Bernhard Hollander, Riga 1926 (o Suworowie zob. s. 36-58; o budowie portu zob. s. 42).

${ }_{26}$ [Arnold Tideböhl], Fürst Alexander Suworow, General-Gouverneur von Liv-, Est- und Kurland 1848-1861. Erster Abschnitt: Riga, Riga 1862; Анатолий Нарежный, «Гуманный внук воинственного деда» Александр Суворов-младший и его либеральное управление Остзейским краем, https://www.colta.ru/articles/specials/18772-gumannyy-vnuk-voinstvennogo-deda [dostęp: 7.02.2020].

${ }_{27}$ Bardzo dokładny opis wszystkich kolejnych kroków zob. Die Abtragung der Festungswerke Rigas und die damit verbundenen Communalbauten. Bericht und Rechenschaft der ständischen Commission, Riga, 1864, s. 2-6. Jest to niezwykle intersujący dokument, zawierający nie tylko detaliczny opis prac wykonanych w latach 1857-1863, lecz także kosztorysy oraz odpisy najważniejszych dokumentów. 
Agnieszka Zabłocka-

- Kos

na budowę targów, hal i magazynów, wreszcie teatru i wodociągów. Zdaniem Suworowa ówczesne umocnienia nie spełniały już funkcji obronnych, co pokazały wydarzenia wojny „orientalnej”, jak określano wojnę krymską.

Pod wpływem memoriału już 14 marca 1856 r. powołano komisję, która opracowała wstępną koncepcję zagospodarowania terenów pofortyfikacyjnych i określiła koszty likwidacji umocnień ${ }^{28}$. Przewidywano zachowanie niektórych bastionów i części fos, wokół których planowano założenie promenad oraz wzniesienie reprezentacyjnych budowli publicznych (teatru, gimnazjum), gazowni, dużego basenu portowego i przede wszystkim dworca kolejowego. Plan poglądowy przygotował architekt miejski, Johannes Daniel Felsko (1813-1902) ${ }^{29}$ (il. 7). Koncepcja, wraz z niezwykle szczegółowo opracowanym projektem i zakresem prac oraz kosztorysami, została przedstawiona carowi w czerwcu tegoż roku ${ }^{30}$. Prace miały być sfinansowane z kredytu. W dniu 26 sierpnia 1857 r. na mocy rozkazu carskiego umocnienia zostały nieodpłatnie zwrócone miastu ${ }^{31}$, co pozwalało na ich demontaż $\dot{z}^{32}$.

W dniu 15 listopada 1857 r. nastąpiło niezwykle uroczyste rozpoczęcie rozbiórki wałów, relacjonowane szczegółowo w prasie ${ }^{33}$. O godzinie dziewiątej rano uformowano pochód, który otwierały orkiestra instrumentów dętych i chór. Za nimi kroczyli: komisja powołana do przeprowadzenia defortyfikacji na czele z burmistrzem Rygi, członkowie rady miejskiej i przedstawiciele różnych organizacji. Pochód zamykał znany chór męski „Liederkranz”. Do demolicji przystąpiono przy Bramie Piaskowej (Sandpforte), ozdobionej flagami, śpiewając specjalnie na tę okazję ułożony hymn Hin sinkt der Wall, der alte Schutz. Es fallen seine Stützen. Po przemówieniu burmistrza odśpiewano hymn państwowy. Następnie burmistrz i członkowie

28 Szczegółowy kosztorys opiewał na 1,5 mln rubli, zob. ibidem, s. 9 i n.; Campe, Die Stadtore Riga..., s. 353-357. Do komisji powołano m.in. inżyniera Henningsa z Lubeki, co potwierdza bliskie związki z tym miastem, zważywszy, że projekt promenad wykonał inż. Wendt, też z Lubeki; zob. ibidem, s. 354.

29 Szczegółowo i najpełniej na temat planu Rygi Felsko pisze Daina Lāce, Rīgas plānojums 19. gs. vidū: Esošais un vēlamais [w:] Pilsēta. Laikmets. Vide. Rakstu krājums, Sast. Rūta Kaminska, Rīga 2007 (Materiāli Latvijas mākslas vēsturei), s. 36-59; eadem, Pirmais Rīgas pilsētas arhitekts Johans Daniels Felsko (1813-1902), Rìga 2012 (Dissertations of the Latvian Academy of Art, Institute of Art History, t. III), s. 83-100; eadem, City architect of Riga Johann Daniel Felsko 1813-1902, Riga 2011, s. 14-17; Zdzisława Tołłoczko, Johann Daniel Felsko (1813-1902): architekt i urbanista - twórca nowoczesnej Rygi. Johann Daniel Felsko (1813-1902): an architect and urban planner - the creator of modern Riga, „Wiadomości Konserwatorskie” 2008, t. 24, s. 7-16, eadem, Architectura sine Historiae nihil est. Z dziejów architektury i urbanistyki ziem Łotwy, Kraków 2013, s. 171-185; zob. też Bākule, Siksna, Rìga ärpus..., s. 140-148.

30 Die Abtragung..., s 113-122; Bākule, Siksna, Rīga ärpus..., s. 148.

31 Państwo zabrało je podczas kampanii napoleońskiej.

32 Die Abtragung..., s. 8-13; Mettig, Geschichte der Stadt..., s. 455; Brunstermann, Die Geschichte..., s. 486; Lāce, Rīgas plānojums..., s. 36-59.

33 Pełny opis zob. „Rigasche Zeitung” 1857, nr 268, s. 1, 2; Brunstermann, Die Geschichte..., s. 486-490; „Rigascher Rundschau” 1932, nr 259, s. 7. 


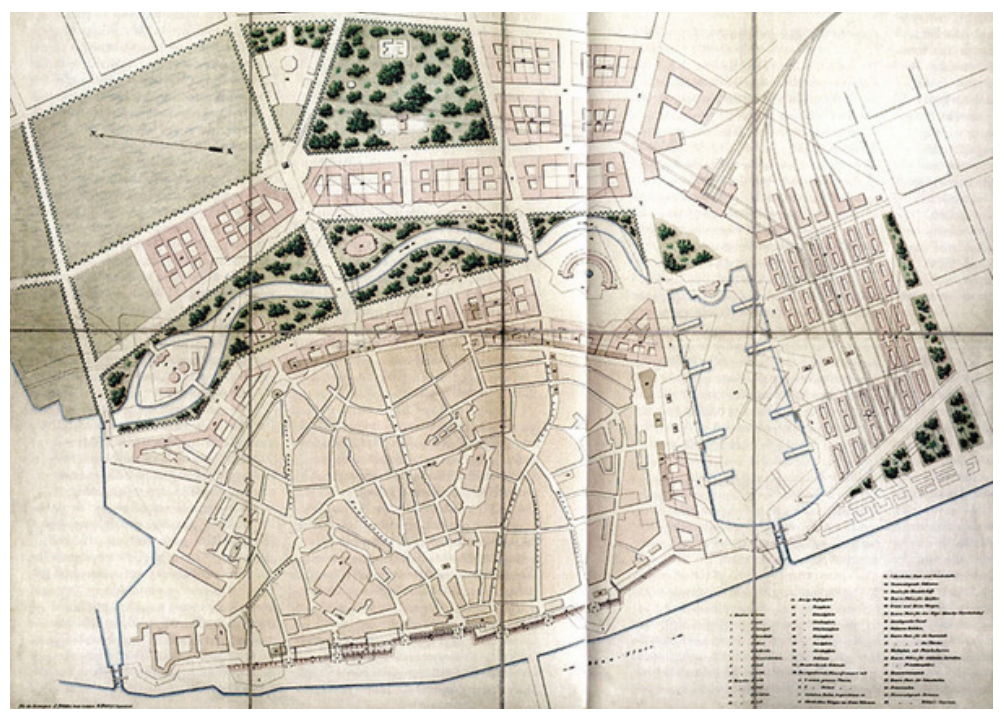

Hin sinkt der Wall...

Il. 7. Johann Daniel Felsko, projekt zagospodarowania terenów pofortyfikacyjnych, 1857, rep. za: Wikipedia

komisji rozpoczęli rozbiórkę, używając specjalnej łopaty ozdobionej portretem cara i wizerunkiem pamiątkowego medalu z $1810 \mathrm{r}^{34}$ Temu aktowi towarzyszyła pieśń Lutra - hymn protestancki Ein’ feste Burg ist unser Gott. W prasie podkreślono, że w tym momencie wyjrzało słońce, co wszyscy przyjęli za dobry znak i pomyślną wróżbę. Pierwszą część uroczystości zakończono przed ratuszem, wygłaszając mowę na cześć gubernatora Suworowa, następnie udano się do resursy kupieckiej na uroczyste śniadanie. Jednakże prawdziwie ludowe obchody tego wydarzenia odbyły się wieczorem. Przez iluminowane miasto przeszedł pochód oświetlony pochodniami, na czele z burmistrzem i członkami Wielkiej i Małej Gildii niosącymi chorągwie. Uroczystość uświetniła oprawa muzyczna w wykonaniu orkiestry dętej i chórów. Przy dźwiękach marsza udano się na wały, by tam przy wtórze serenady i śpiewnego adagio dokonać „aktu pożegnania”. Wydarzenie to łączyło elementy podniosłych państwowych uroczystości (choć, co charakterystyczne, bez udziału wojska) z rodzajem ludowej, karnawałowej fiesty. Społeczność miasta świętowała początek nowej ery, zdając sobie sprawę z tego, że likwidacja fortyfikacji umożliwi metropolitalny rozwój Rygi. Obchody związane z demontażem ryskich umocnień należą do jednych $z$ niewielu tak hucznie i radośnie przeprowadzonych aktów defortyfikacji w miastach europejskich.

Realizacja całego przedsięwzięcia była skomplikowana i wymagała zgód odpowiednich władz centralnych. Ministerstwo Spraw Wewnętrznych na podstawie bardzo szczegółowego planu działań i rysunków zatwierdzało m.in. zgodę

34 Łopatę oddano do archiwum miejskiego. 
Agnieszka Zabłocka-

- Kos

na udzielenie pożyczki. Aby szybko splantować wały, wytyczyć i wybrukować drogi i działki, utworzono duże biuro projektowe, w którym zatrudniono wielu architektów i inżynierów. Pierwszy plan autorstwa Johanna Daniela Felsko z 1857 r. okazał się za drogi w realizacji, został więc do czerwca 1858 r. opracowany na nowo i w wielu miejscach istotnie zmieniony przez Juliusa Augusta Hagena (1829-1909)

Projekt Hagena był niestety dużym uproszczeniem koncepcji Felsko, która należy niewątpliwie do najciekawszych propozycji zagospodarowania terenów pofortyfikacyjnych, jakie powstały w Europie w XIX w. Felsko wykorzystywał koncepcję przestrzenną wykreowaną przez Paullucciego. Plan charakteryzuje się bardzo nowoczesnym podejściem do strefowania funkcjonalnego miasta, co było w tym czasie jeszcze dużą rzadkością. Felsko wprowadził wyraźny podział na strefę handlowo-komunikacyjną oraz część reprezentacyjno-parkową. W nowym obszarze wyróżnił tereny związane z infrastrukturą techniczną, zlokalizowane nad Dźwiną oraz na północny zachód od starego miasta. Jako że obawiano się powodzi, architekt zaproponował pozostawienie od strony rzeki części umocnień i zbudowanie wzdłuż nich arkadowych pasaży handlowo-magazynowych. Pięć masywnych bram z wieżami (w miejscu dawnych bram) $\mathrm{w}$ formach gotyku angielskiego świetnie wpasowywałoby się $\mathrm{w}$ panoramę miasta od strony Dźwiny. Pod względem funkcjonalnym koncepcja ta (arkady handlowo-magazynowe) przypominała rozwiązania londyńskich tarasów mieszkalno-handlowych Adelphi (1768-1772) autorstwa braci Adam (w części nad Tamizą) ${ }^{36}$. Równocześnie jednak tworzyła mentalną asocjację z przeszłością i średniowieczną potęgą miasta należącego do Hanzy. Ten przekaz byłby z pewnością skierowany do kupców przybywających tu drogą morską. Od strony północnej do łączącego się z rzeką dużego basenu portowego przylegały place i magazyny, połączone torami z zapleczem kolejowym i odgrodzone pasami zieleni od pozostałej zabudowy. Nabrzeże i basen portowy tworzyły zatem bardzo dobrze przemyślną infrastrukturę, związaną z handlem morskim i rzecznym. Znakomicie zlokalizowano dworzec czołowy - bezpośrednio przylegający do miasta, poprzedzony zielonym skwerem łączącym się z promenadą. Na dawnym glacis od strony zachodniej Felsko przewidział park krajobrazowy z pawilonami, rozplanowany wokół zachowanej fosy. Łącznikiem architektoniczno-funkcjonalnym między promenadą a strefą dworca i portu był "gościnny dwór”, typowa dla Rosji budowla targowa z podcieniami. Park ujmowałyby z obu stron pierzeje kamienic, można się domyślić, że w formie pałaców czynszowych, wypełniające pierzeję także od strony basenu portowego. Było to „otwarte i malownicze” pendant do „obronnego”

35 Die Abtragung..., s. 15-16 (opis drugiego planu zob. s. 124-136; porównanie kosztorysów obu propozycji zob. s. 138-141).

36 Joseph und Anne Rykwert, Robert und James Adam. Die Künstler und der Stil, Stuttgart 1987, s. 150-151; Austin Brereton, The Literary History of the Adelphi and its Neighbourhood, New York 1909. 
nabrzeża rzeki. Szeroka aleja zakończona okrągłym placem z pomnikiem pośrodku łączyłaby stare miasto z esplanadą (placem ćwiczeń) i parkiem der Wall... Wöhrmanna, założonym, zgodnie z planem Paulucciego, w $1817 \mathrm{r}$.

Plan Felsko chętnie porównuje się z planami wiedeńskiego Ringu. W stolicy Austrii już od początku lat pięćdziesiątych XIX w. toczyły się dyskusje na temat zagospodarowania glacis, jednak plan Felsko został sporządzony ponad rok wcześniej przed ogłoszeniem wyników wielkiego konkursu na projekt Ringu. A zatem koncepcja ryska wyprzedziła wiedeńską. Idea Felsko wykazuje, jak sądzę, najwięcej podobieństw z zagospodarowywanymi od $1806 \mathrm{r}$. terenami pofortyfikacyjnymi we Frankfurcie nad Menem. Tam również pozostawiono fosę i niektóre bastiony, a tereny zielone obudowano eleganckimi kamienicami tworzącymi nowe pierzeje zarówno od strony staromiejskiej, jak i przedmieśćc ${ }^{37}$. Duże zbieżności z Frankfurtem wykazuje też lokalizacja reprezentacyjnych budowli publicznych, a szczególnie teatru. Inspiracją mogły być także promenady we Wrocławiu, Bremie i Lubece, powstałe na początku XIX w., w których zachowano fosy.

Już w 1859 r. odbyły się pierwsze licytacje parcel na terenach pofortyfikacyjnych $^{38}$. Dla nowo zabudowywanych terenów opracowano nowe przepisy budowlane. Działki miały mieć od frontu szerokość minimum 50 stóp (rosyjskich, tj. 15 m). Zakładano, że budynki powinny być murowane, nakryte niepalnym dachem i tworzyć zwarte pierzeje nie wyższe niż $24 \mathrm{~m}^{39}$. Domy cofnięte w stosunku do linii regulacyjnej, powinny być ogrodzone murem lub ozdobnym płotem na podmurówce. Każdy projekt należało zatwierdzić $\mathrm{w}$ odpowiednim urzędzie budowlanym ${ }^{40}$.

Prace rozbiórkowe ukończono w 1863 r., a linię kolejową otwarto rok wcześniej. W ten sposób Ryga wkroczyła na początku lat sześćdziesiątych XIX w. w okres intensywnego, metropolitalnego rozwoju (il. 8). Pierwszymi publicznymi budynkami były dworzec kolei Ryga-Dyneburg i teatr, które stanęły na niemal pustej promenadzie (il. 9-10). W ciągu dekady działki zostały zabudowane, tworząc jedno z najpiękniejszych założeń promenadowych w Europie - ze wspaniałymi budowlami użyteczności publicznej (gimnazjum, siedzibą Politechniki), pałacami, kamienicami i eleganckim korso nad rzeką (il. 11-12). Na początku XX w. Ryga była trzecim największym miastem na wschód od Odry (po Warszawie i Wrocławiu) z bardzo dobrze rozwijającym się przemysłem, licząc w 1913 r. ponad 470000 mieszkańców ${ }^{41}$. Koncepcje jej przestrzennego rozwoju, nakreślone w planach nowożytnych i dziewiętnastowiecznych, znalazły wówczas swoją pełną realizację.

\footnotetext{
37 Björn Wissenbach, Mauern zu Gärten. 200 Jahre Frankfurter Wallanlagen, Frankfurt am Main 2010

38 Die Abtragung..., s. 30. Cena za 1 sążeń kwadratowy wynosiła od 25 do 52 rubli.

39 Bākule, Siksna, Rīga ārpus..., s. 151. Autorki wskazują na podobieństwo tych przepisów z paryskimi, tu jednak chyba bardziej należałoby odnieść się do przepisów berlińskich z 1853 r., zob. Bau-Polizei-Ordnung für die Stadt Berlin, vom 21. April 1853, Berlin 1853.

40 Die Abtragung..., s. 147-150.

${ }^{41}$ W 1914 r. Warszawa liczyła 884000 mieszkańców, Wrocław w 1911 r. - 536000.
} 


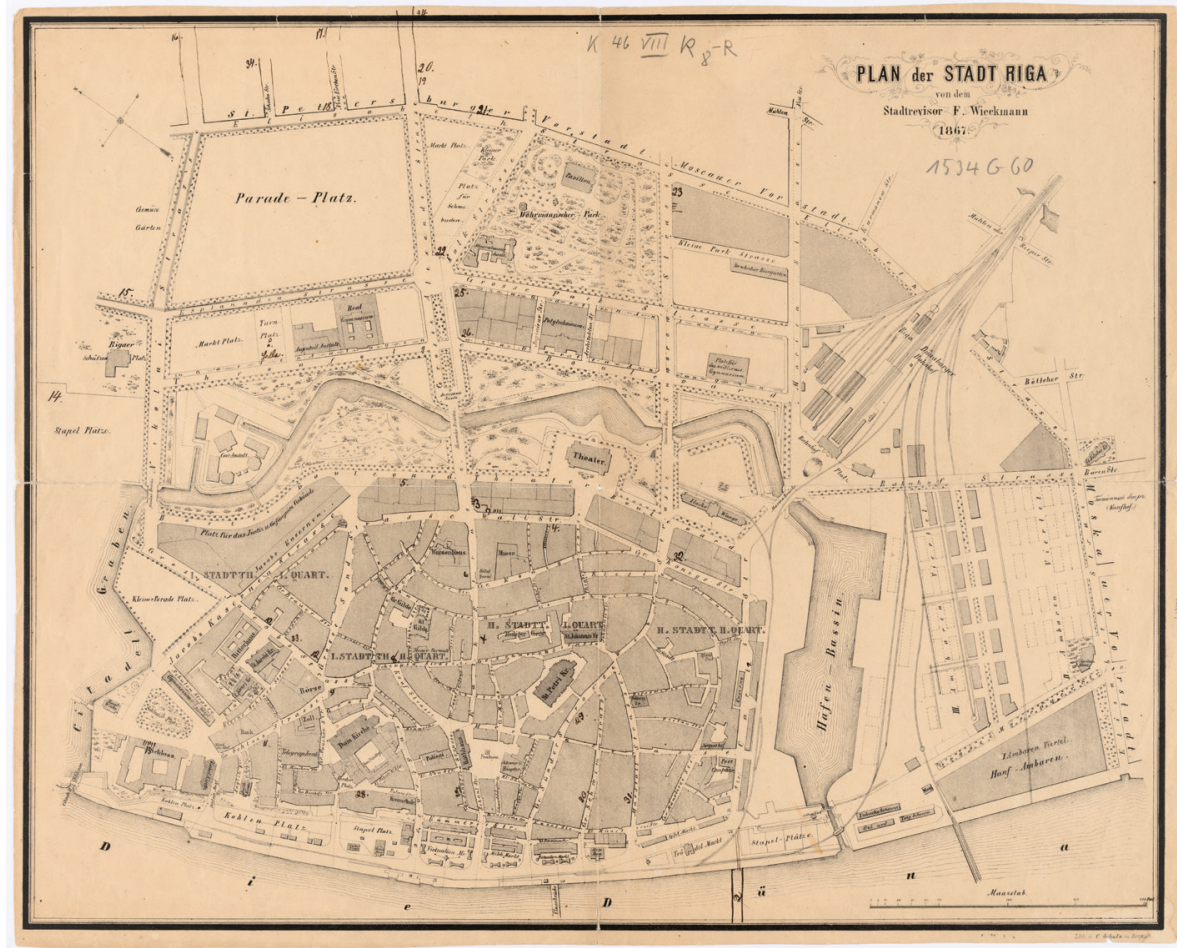

Il. 8. Plan der Stadt Riga, bearb. F. Wieckmann, 1867, Herder Institut Marburg, Kartensammlung sygn. K 46 VIII R 8-R

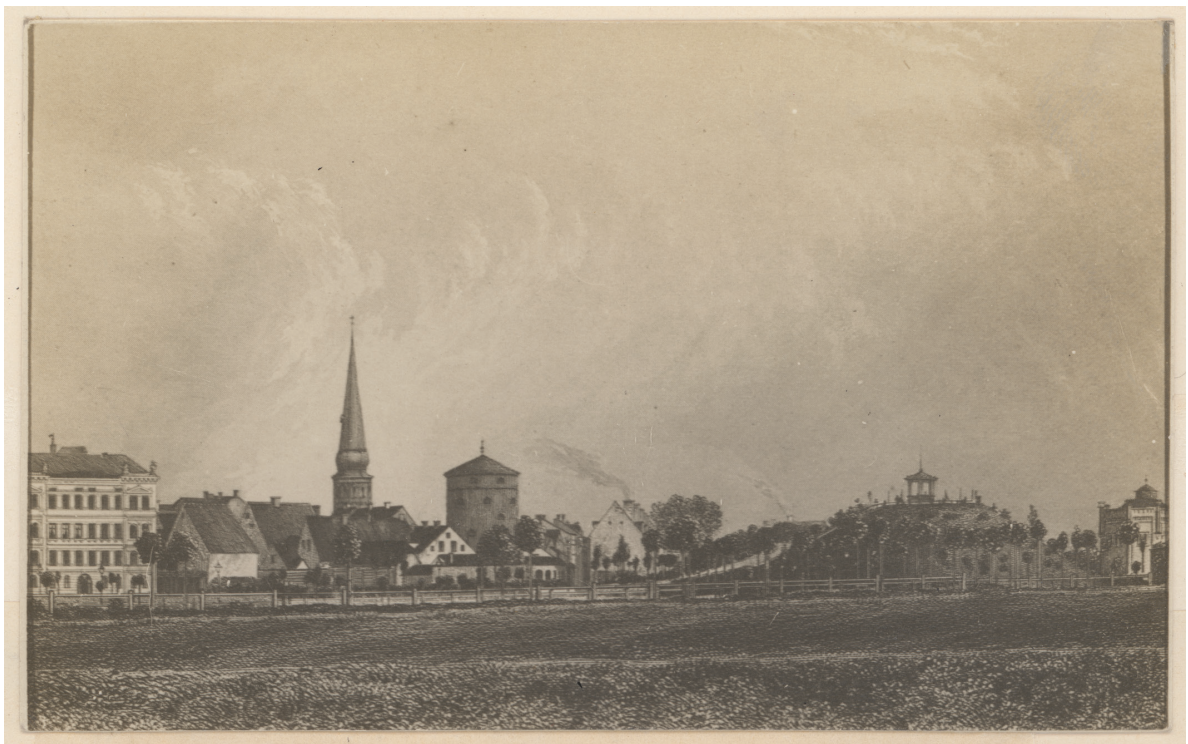

Il. 9. Ryga, widok na stare miasto i promenadę, po lewej stronie nowa kamienica, po prawej stronie gazownia, na dawnym bastionie pawilon upamiętniający wizytę następcy tronu Mikołaja Aleksandrowicza w 1860, Herder Institut, Bildarchiv Sammlung Campe, nr 252839 


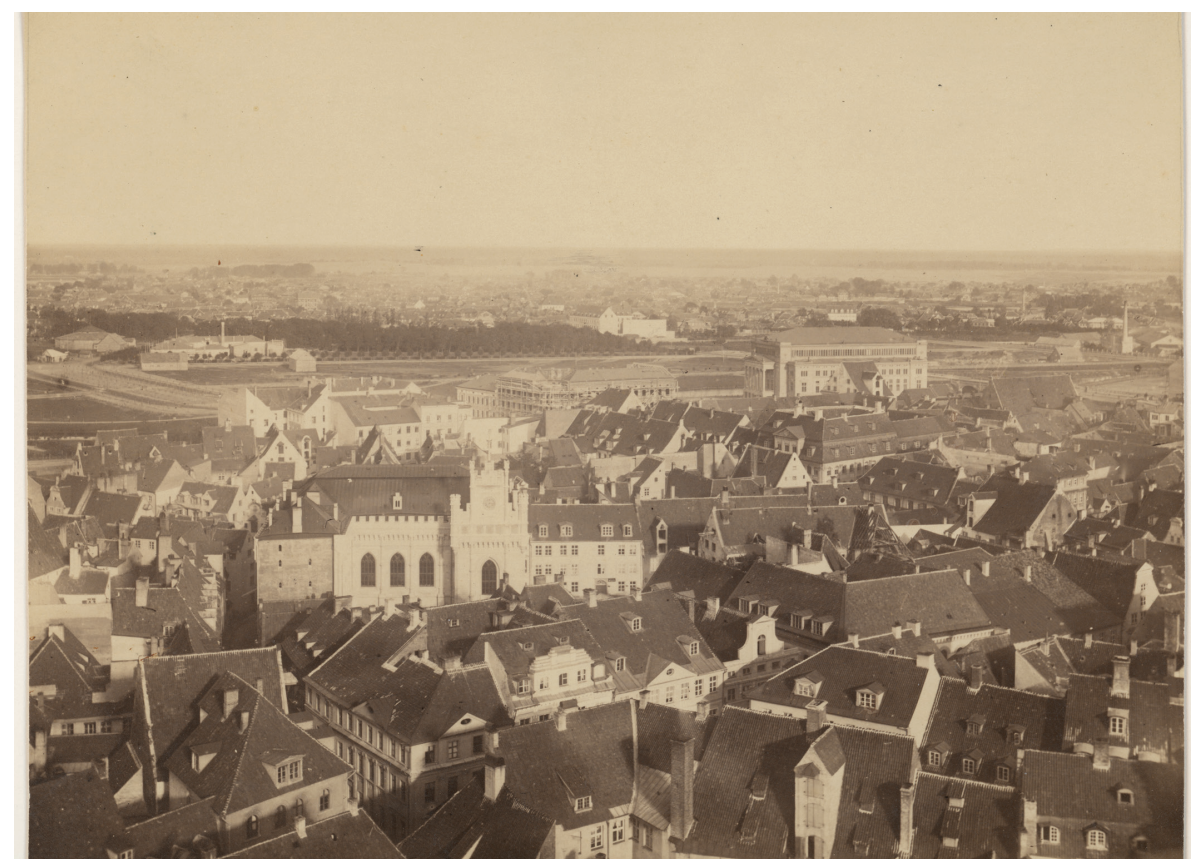

Il. 10. Ryga, widok na stare miasto i nową promenadę, w głębi po prawej stronie teatr, około 1862, fot. Alfons Behrmann, Herder Institut, Bildarchiv Sammlung Campe, nr 252853

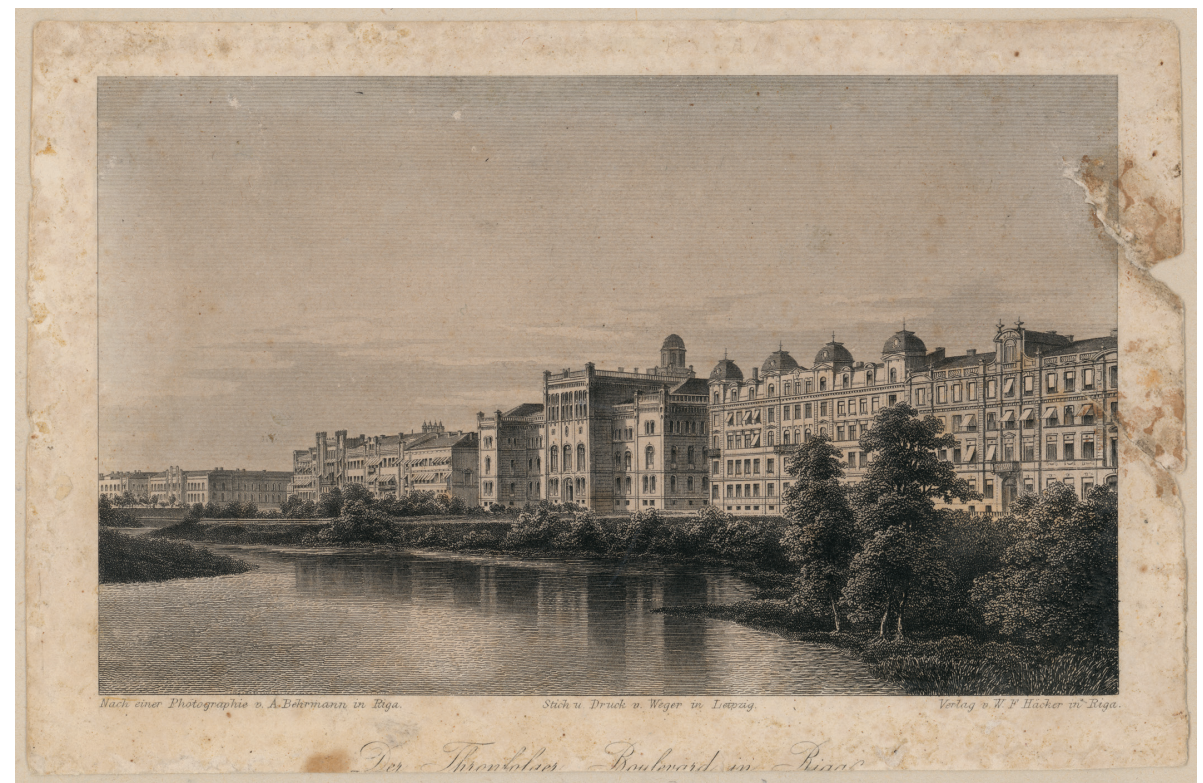

Il. 11. Ryga, widok na Thronfolger Boulevard (ob. Raina bulvaris), według fotografii Alfonsa Behrmanna, sztych i druk Weger Lipsk, Herder Institut Marburg, Bildarchiv Sammlung Campe, nr 252852 


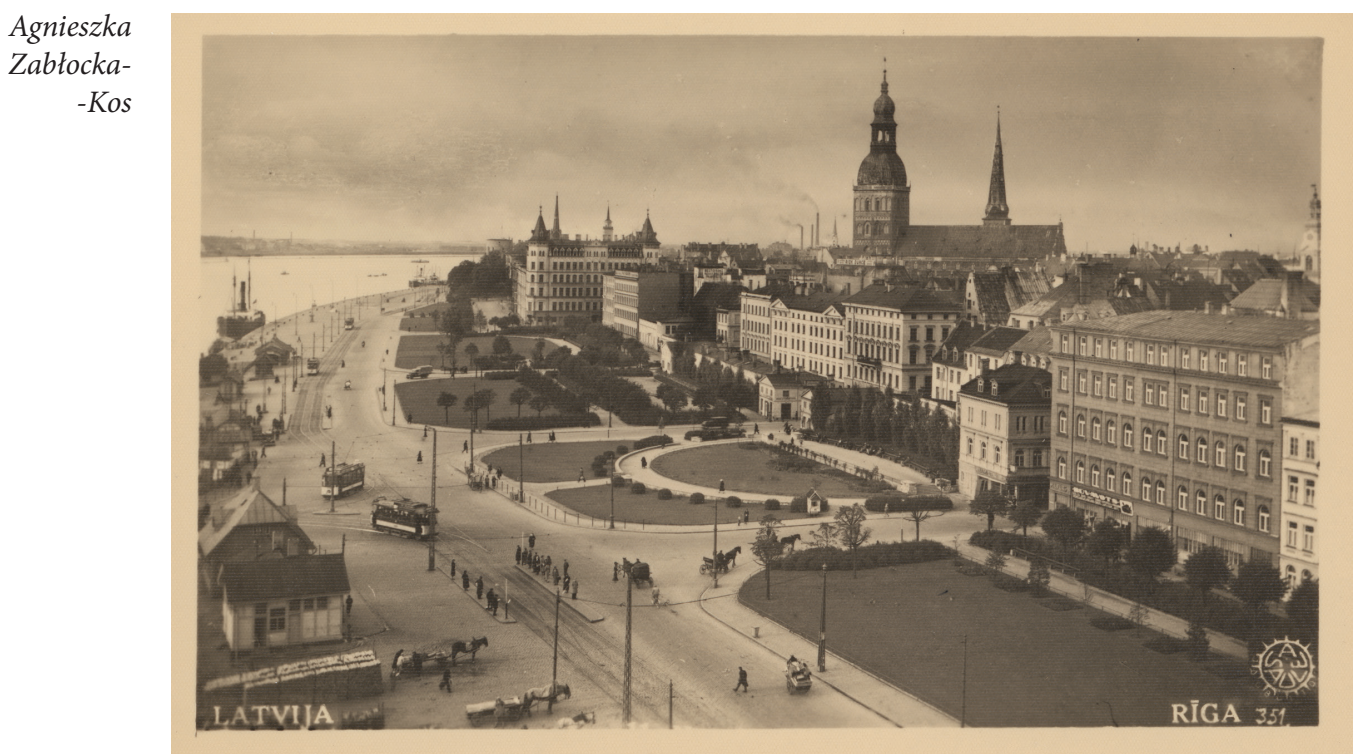

Il. 12. Ryga, wybrzeże nad Dźwiną, pocztówka, okres międzywojenny, Herder Institut, Bildarchiv Sammlung Campe, nr 252840

\section{Bibliografia}

Bākule Irēna, Siksna Arnis, Rīga ārpus nocietinäjumiem: pilsētas plānota izbūve un pärbuve / Riga beyond the walls The city's planned growth and transformation from the 17th century to the First World War, Riga 2009.

Brunstermann Friedrich, Die Geschichte der Kleinen oder St. Johannis-Gilde in Wort und Bild (zum Jubiläumsjahr 1901), Riga 1902.

Campe Paul, Die Stadtore Riga im 17., 18., 19. Jh. und deren Meister [w:] Latvijas Universitates Raksti Acta Universitatis Latviensis Architektura Fakultates Serija II.3, Riga 1939, s. 241-360.

Die Abtragung der Festungswerke Rigas und die damit verbundenen Communalbauten. Bericht und Rechenschaft der ständischen Commission, Riga 1864.

Lāce Daina, Rīgas plānojums 19. gs. vidū: Esošais un vèlamais (Riga planning in the mid19th century: reality and aspirations) [w:] Pilsēta. Laikmets. Vide: Rakstu krājums (= Materiāli Latvijas mākslas vēsturei), ed. Rūta Kaminska, Rīga, 2007.

Lāce Daina, Pirmais Rīgas pilsētas arhitekts Johans Daniels Felsko (1813-1902) / The First Riga City Architect Johann Daniel Felsko (1813-1902), Rīga 2012 (LMA Mākslas vēstures institūts; Rīga: Mākslas vēstures pētījumu atbalsta fonds).

Lāce Daina, City architect of Riga Johann Daniel Felsko 1813-1902, Rīga 2011.

Mintzker Yair, The Defortification of the German City, 1689-1866, Cambridge 2012.

Omilanowska Małgorzata, Defortyfikacja Gdańska na tle przekształceń miast niemieckich w XIX wieku, „Biuletyn Historii Sztuki” 2010, nr 3, s. 293-334. 
Omilanowska Małgorzata, Die Entfestigung Danzigs im Kontext der Umgestaltung der deutsche Städte im Laufe des 19. Jahrhunderts [w:] Das maritime Stadt. Hafenstädte an der Ostsee vom Mittelalter bis in die Gegenwart: Beiträge der 21. Tagung des Arbeitskreises deutscher und polnischer Kunsthistoriker und Denkmalpfleger in Gdańsk 18-21 September 2013, Hg. Tomasz Torbus, Katarzyna Anna Wojtczak, Warszawa 2017 (Wspólne dziedzictwo, t. 10 / Das Gemeinsame Kulturerbe, Bd. 10), s. 315-360. Reglement über die Wiederaufbauung der Rigaschen Vorstädte und das Verhältniß der Vorstädte zu den Befestigungen von Riga, Riga 1813.

Wissenbach, Björn, Mauern zu Gärten. 200 Jahre Frankfurter Wallanlagen, Frankfurt am Main 2010.

\section{The Riga Fortress in the $16^{\text {th }}-19^{\text {th }}$ Centuries and Its De-fortification in 1857}

The following article presents the issue of the fortification of Riga and associated plans of the suburbs in the $17^{\text {th }}$ and $18^{\text {th }}$ centuries (plans of Johann van Rodenburg and Rudolf Friedrich Härbel), as well as the projects of the transformation of the former fortification zones in the $19^{\text {th }}$ century. Additionally, the paper covers the question of an unknown plan of Riga from 1843. In 1812, as a result of an intentional arson during the Russian campaign, the suburbs were completely destroyed. This prompted Filippo Paulucci to create a new plan that, among others, carefully delineated the transformation of the glacis into a wide esplanade. In 1856, after the Crimean War, a decision was made to de-fortify the city. In November 1857, in a very solemn manner, the process of Riga's defortification began. Torch-bearing citizens participated in marches across the city, taking part in concerts and collective singing; during all these festivities, the city was brightly illuminated. This event was an amalgamation of solemn state celebrations and a folk, carnival-like fiesta. Celebrations connected with the process of Riga's defortification belong to a small group of defortifications in European cities celebrated so uproariously.

In early 1857, the architect Johann Daniel Felsko created a remarkably interesting plan developing the former fortification grounds, as well as a new idea of the spatial development of the city. Felsko used the modern division into functional zones: the trading-communication zone (port, depots, railway station, and 'gostiny dvor' ('merchant yard') and the stately-park zone (palaces, elegant revenue houses, public buildings), which, at that time, was still a great rarity. The conception utilized in Riga definitely overtook the ideas for the Vienna Ring Road (the second half of 1857). In my opinion, Felsko's idea shares the most similarities with the former fortification zones in Frankfurt am Main, which were reclaimed in 1806 . However, his plan was never faithfully realized.

Out of numerous projects concerning the esplanade and promenade on the grounds of the former glacis, in the second half of the $19^{\text {th }}$ century, there emerged one of the most interesting and beautiful European promenade complexes. Some of the first public buildings were the Riga-Daugavpils Railway Station and the theatre; later, school buildings, the Riga Technical University, and numerous palaces and houses were erected there. In the early $20^{\text {th }}$ century, Riga was the third biggest and industrially developed city east of the Oder, reaching the population of over 470,000 citizens in 1913, following Warsaw and Wrocław. Its spatial development ideas, created in the $19^{\text {th }}$ century, were then fully implemented. 